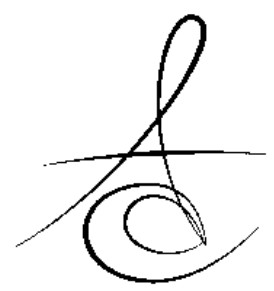

\title{
ORTHODONTIC TREATMENT OF A PATIENT WITH TRANSVERSE MAXILLARY CONSTRICTION AND SEVERAL IMPACTED TEETH
}

\author{
ÜST ÇENE DARLIĞI VE ÇOK SAYIDA GÖMÜK DİŞLERİ OLAN BİR \\ HASTANIN ORTODONTİK TEDAVİSI
}

Dr. Esma DOLAP*
Prof. Dr. Nihat KILIÇ**

\author{
Makale Kodu/Article code: 4414 \\ Makale Gönderilme tarihi: 05.06 .2020 \\ Kabul Tarihi: 08.10.2020 \\ DOI : $10.17567 /$ ataunidfd.807481
}

Esma Dolap: ORCID ID: 0000-000-3296-6582

Nihat Kılıç: ORCID ID: 0000-0002-1753-1380

\begin{abstract}
Multiple impacted permanent teeth are uncommon and rarely reported in the literature. Impacted tooth or teeth cause esthetics and functional problems. Forced-eruption of impacted tooth into the proper position in the arch may provide better functional outcomes, and it also provide esthetic smile for the patient. This case reports the treatment of an adult patient with constricted maxillary arches, multiple impacted teeth and a supernumerary tooth. Forced-eruption of the impacted tooth by light forces generated by intermaxillary elastics, rapid maxillary expansion, and finally fixed appliance treatment was done. Because of the long-lasting orthodontic treatment period, the patient preferred to complete the treatment without detailed occlusion and proper inter-occlusal relationship were achieved. The treatment results showed that maxillary constriction eliminated, eight impacted teeth positioned into proper alignment, and acceptable esthetic and functional results were obtained.
\end{abstract}

Keywords: Impacted tooth, rapid maxillary expansion, orthodontic treatment

\section{öz}

Çok sayıda dişin gömük kalması nadiren meydana gelir ve literatürde de nadiren rapor edilmiştir. Gömük olan dişler, estetik ve fonksiyonel problemlere sebep olur. Gömük olan dişlerin, ark üzerinde doğru pozisyona kuvvet uygulanarak sürdürülmesi hastada daha iyi bir fonksiyon sağladığı gibi, aynı zamanda hastada estetik bir gülümseme sağlayabilir. Bu vaka raporunda, üst çene darlığı, çok sayıda gömük dişleri ve süpernumerer bir dişi olan hastanın ortodontik tedavisi sunulmuştur. Hastaya çeneler arası elastiklerle hafif kuvvet uygulanarak gömük dişlerin sürdürülmesi, hızlı üst çene genişletmesi ve son olarak sabit ortodontik tedavi uygulanmışır. Ortodontik tedavinin uzun dönem devem eden sebebiyle, hasta detaylı bir okluzyon ve uygun inter-oklüzal ilişki sağlanmadan tedavisinin tamamlanmasını tercih etmiştir.

Tedavi sonuçları, üst çene darlığının giderildiğini, 8 adet gömük diş̧n sürdürüldüğünü ve seviyelendiğini ve kabul edilebilir estetik ve fonksiyonel sonuçların elde edildiğini göstermiştir.

Anahtar kelimeler: Gömük diş, hızlı üst çene genişletmesi, ortodontik tedavi

* Bayburt Özel Diş Kliniği

${ }^{* *}$ Atatürk Üniversitesi, Diş Hekimliği Fakültesi, Ortodonti Anabilim Dalı, Erzurum

Kaynakça Bilgisi: Dolap E, Kılıç N. Üst çene darlığı ve çok sayıda gömük dişleri olan bir hastanın ortodontik tedavisi. Atatürk Üniv Diş Hek Fak Derg 2021; 31: 279-82.

Citation Information: Dolap E, Kilic N. Orthodontic treatment of a patient with transverse maxillary constriction and several impacted teeth. J Dent Fac Atatürk Uni 2021; 31: 279-82.

\section{INTRODUCTION}

Tooth impaction can be described as the intraosseous position of the tooth after expected eruption time. ${ }^{1}$ Tooth impaction most commonly occurs in mandibular third molars, maxillary third molars, maxillary canines, mandibular premolars, and maxillary incisors. Lower incisors and canines and other molars are more rarely impacted.
Local and general factors may influence the etiology of impacted tooth. 2,3,4 Local factors include; space deficiency, premature missing or persistent of deciduous tooth, presence of supernumerary tooth, alveolar cleft, ectopic germ position, root dilaceration, pressure of neighboring teeth, chronic inflammation of mucosa, increased density in bone structure and soft tissue, inflammatory or pathological changes in surrounding bone (odontoma, cyst, neoplasm, etc.) 
and alveolar and dental trauma. General factors include heredity and systemic causes such as rickets, anemia, congenital syphilis, tuberculosis and endocrine disorders. ${ }^{5-7}$ Cleidocranial dysplasia, which is one of the hereditary factors, is a disease characterized by multiple impacted teeth. ${ }^{8,10}$

Multiple impacted permanent teeth are uncommon and rarely reported in the literature. Multiple impactions cause serious problems in terms of esthetics and functional. Forced-eruption of impacted tooth into the proper position in the arch may provide better functional outcomes, and it also provide esthetic smile for the patient.

This case reports the treatment of a female adult patient with constricted maxillary arches, multiple impacted teeth and a supernumerary tooth.

\section{CASE REPORT}

17 years old female patient referred to the Department of Orthodontics at Atatürk University Faculty of Dentistry with a chief complaint of impacted teeth and non-aesthetic smile. The patient had a flat profile and symmetrical face structure (Figure 1). The medical history of the patient showed that there was no systemic disease and no trauma. There were not similar anomalies in her family members.

Clinical and radiological examination revealed that eight permanent teeth were impacted (all canines, upper and lower right lateral incisors and upper right central incisor) and three molar teeth (all first molar teeth, except upper left first molar) were extracted. It was also observed that the patient still had deciduous teeth (upper left and lower right canines) and she had a supernumerary tooth on the lower left anterior region (Figure 2,3). In addition, patient had constricted maxillary arch and posterior crossbite on both sides (Figure 1).

\section{Treatment Objectives}

The main treatment objective was to expand the constricted maxillary arches and guided and forced-eruption of the impacted teeth to obtain a functional occlusion. The orthodontic treatment plan required (1) surgical exposure of all impacted teeth and ligates all impacted teeth and then forcederuption of the teeth into their spaces, (2) rapid maxillary expansion (3) full fixed orthodontic therapy for proper alignment of all teeth and detailing the occlusion.

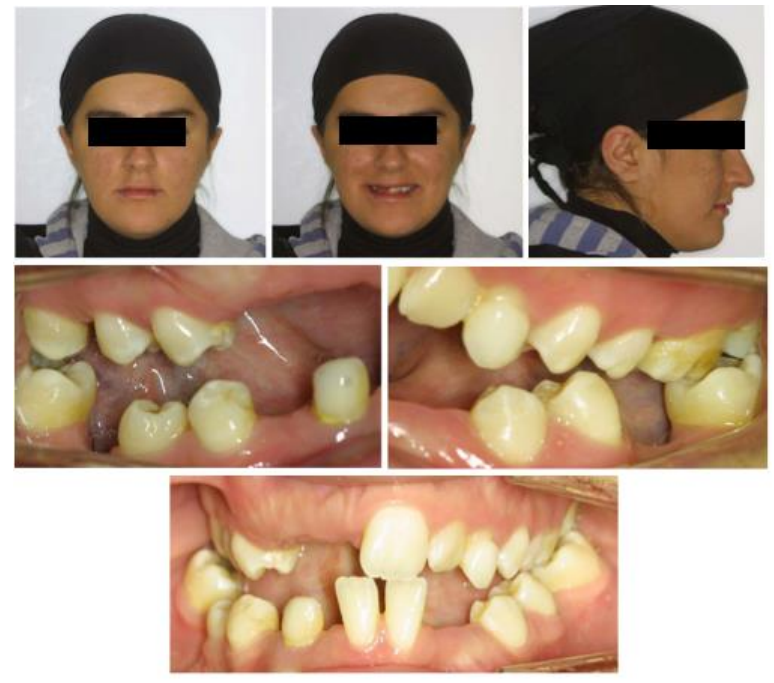

Figure 1. Pre-treatment intraoral and extra-oral photographs.
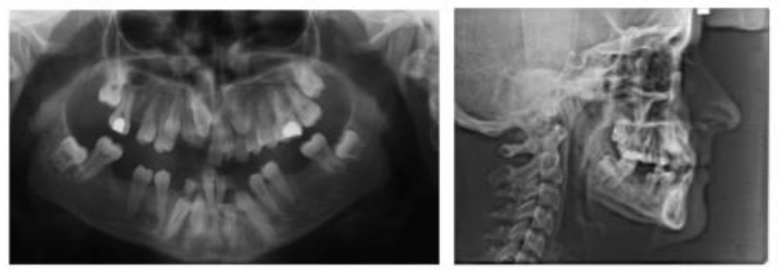

Figure 2. Pre-treatment radiographs.
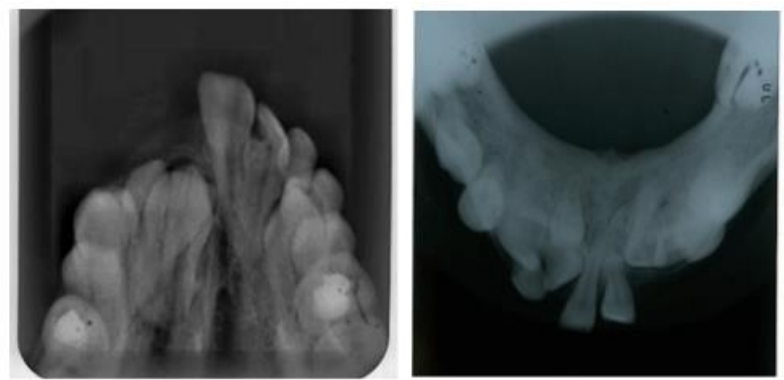

Figure 3. Pre-treatment occlusal radiograph

\section{Treatment Progress}

First of all, deciduous teeth were extracted. The supernumerary tooth located in the lower left anterior region was removed. Impacted teeth in maxilla and mandible were exposed surgically and buttons were bonded to the exposure crowns for orthodontic traction. Inter-maxillary elastics were used between the hooks of buttons to erupt the upper and lower impacted teeth and light reciprocal eruption force between 20-30 gr were applied for 16 months until the teeth eruption was completed.

Rapid maxillary expansion (RME) was planned to expand constricted maxillary arches and correct

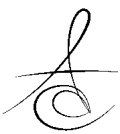


posterior crossbite. Hyrax appliance was applied for RME. The patient was instructed to activate the screw twice a day $(0.4 \mathrm{~mm} / \mathrm{d})$, once in the morning and once in the evening. The patient was called after 7 day later for control. An occlusal radiograph confirmed separation of the mid-palatal suture (Figure 4). Patient continued to turn the screw twice a day to attain the desired width. Expansion was considered adequate when bilateral crossbite and constricted maxillary arch was eliminated. The patient underwent rapid maxillary expansion with 2 turns a day until the expansion screw reached $11 \mathrm{~mm}$.

Finally, tooth alignment was initiated using preadjusted fixed orthodontic appliances. After 18 months of fixed appliances therapy (Roth fixed orthodontic appliance), an acceptable occlusion was achieved.

At the end of the treatment, an aesthetic and functional occlusion was achieved with Class I canine relationship, ideal overjet and overbite. Spaces were prepared for implants between the lower right first and second premolars and the lower first molars previously extracted (Figure 5,6).

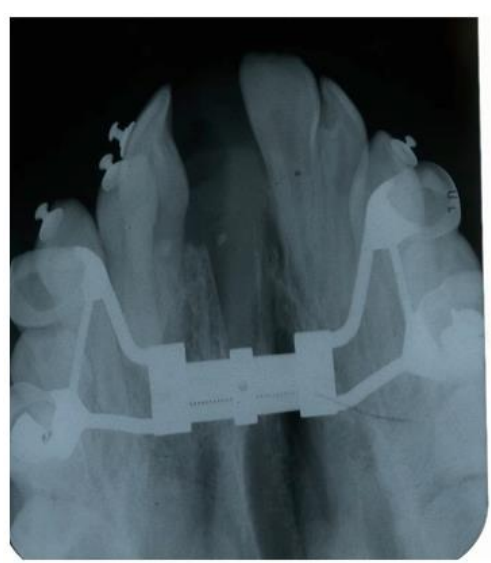

Figure 4. Occlusal radiograph after completion of maxillary expansion.

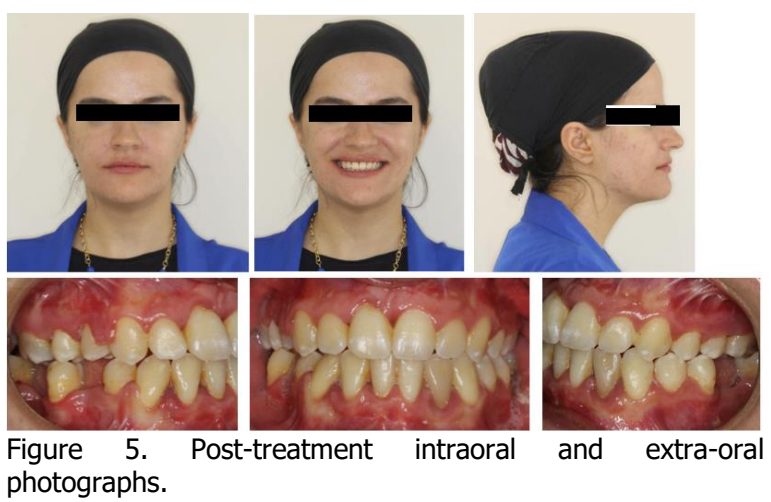

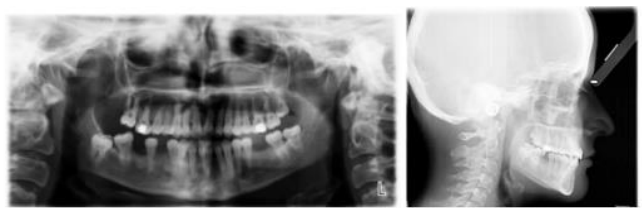

Figure 6. Post-treatment radiographs.

\section{DISCUSSION}

The eruption of anterior impacted teeth is very important in terms of both aesthetics and function. ${ }^{2}$ In addition, impaction of anterior tooth affects patient psychology negatively. There are many reasons why tooth is impacted. The most common reasons of the anterior tooth impaction indicated to be loss of space, supernumerary teeth and odontoma. ${ }^{1-3}$ Multipl teeth impaction is rarely observed and frequently present with a genetic syndrome such as cleidocranial dysplasia (CCD) or endocrine disorder. ${ }^{10}$ In the present patient with several impacted teeth, there was no syndrome or an endocrine disorder. However, the patient had constricted maxillary arches and still deciduous teeth. There was also a supernumerary tooth in the lower left anterior region.

The localization of impacted tooth can be determined by occlusal radiography, panoramic film, periapical film and, if necessary, computed tomography. There are several factors for successful eruption of impacted tooth: (1) the position and direction of the impacted tooth, (2) the degree of root completion, (3) the degree of dilacerations, (4) the presence of space for the impacted tooth. ${ }^{11,12}$ In the patient, considering the position and direction of the eight impacted teeth, it was seen that these teeth were in a sustainable position, there was no root dilatation and the teeth had completed the root development.

In orthodontic treatment of impacted tooth, first of all, it is necessary to create adequate space in the dental arches and then to expose the tooth crowns surgically. ${ }^{2}$ Constriction of maxillary arch may be an in etiological factor for tooth impaction. ${ }^{1-3}$ In our case with maxillary constriction, RME was applied to increase the arc size and provide space for the impacted teeth. Despite the fact that the patient was 17 years old, sutural opening was obtained. After RME, effective tooth eruption was provided with intermaxillary elastics.

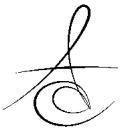


Supernumerary tooth is often located in maxillary incisors region. The frequency of supernumerary tooth in the mandibular incisor region is very rarely. ${ }^{13}$ In our patient, the supernumerary tooth located in the lower left anterior region was removed before surgical exposure.

Fixed appliance, removable appliance, temporary anchorage devices (TADs), elastics, special springs and magnets can be used during the orthodontic treatment of impacted tooth. ${ }^{14}$ In the patient, inter-maxillary elastics which were effective were used to the eruption of teeth. After completing of the teeth eruption, fixed orthodontic treatment was applied to the patient for the leveling and detailing of the arches and this treatment has resulted in acceptable functional and aesthetic results. Because of the long-lasting orthodontic treatment period, the patient preferred to complete the treatment without detailed occlusion and proper inter-occlusal relationship were achieved. Thus, fixed orthodontic appliances were debonded.

The final treatment results showed that maxillary constriction eliminated, eight impacted teeth positioned into proper alignment, and acceptable esthetic and functional results were obtained.

Bu çalışma, çalışmayı yürüten tüm yazarlar tarafindan okunmuş ve onaylanmış orijinal bir çalışmadır. Herhangi bir yazar, kurum ya da kuruluş ile çıkar çatışması olmadığını belirtilmek isteriz.

\section{REFERENCES}

1. Pescia R, Kiliaridis $\mathrm{S}$, Antonarakis GS. Spontaneous eruption of impacted maxillary incisors after surgical extraction of supernumerary teeth: a systematic review and meta-analysis. Clin Oral Investig 2020; 24: 3749-59

2. Ajith SD, Shetty $S$, Husain $H$, Nagaraj T, Srinath $M$. Management of Multiple Impacted Teeth: A Case Report and Review. J Int Oral Healt 2014; 6:93-9

3. Olive RJ. Orthodontic considerations for impacted and ectopic teeth. Aust Orthod J 2017; Spec No: 99-104.

4. Bishara SM. Impacted maxillary canines: A review. American J Orthod Dentofacial Orthop 1992; 101: 159-71.

5. Nagaraj K, Upadhyay M, Yadav S. Impacted maxillary central incisor, canine, and second molar with 2 supernumerary teeth and an odontoma. Am J Orthod Dentofac Orthopedics 2009; 135:390-9.

6. Tanaka E, Kawazoe A, Nakamura S, Ito G, Hirose
N, Tanne Y, Kawai N, Tanimoto K, Tanne K. An adolescent patient with multiple impacted teeth. Angle Orthod 2008; 78:1110-8

7. Fu PS, Wang JC, Wu YM, Huang TK, Chen WC, Tseng $\mathrm{YC}$, Tseng $\mathrm{CH}$, Hung CC. Unilaterally impacted maxillary central incisor and canine with ipsilateral transposed canine-lateral incisor. Angle Orthod 2013; 83: 920-6

8. Kuroda S, Yanagita T, Kyung HM, TakanoYamamoto T. Titanium screw anchorage for traction of many impacted teeth in a patient with cleidocranial dysplasia. Am J Orthod Dentofac Orthop 2007; 131:666-9.

9. Conley RS, Boyd SB, Legan $\mathrm{HL}$, Jernigan CC, Starling C, Potts C. Treatment of a Patient with Multiple Impacted Teeth. Angle Orthod 2007; 77: 735-41

10. Niu Q, Zhang L, Dai J, Li F, Feng X. Orthodontic Management with Traction and asymmetric extraction for multiple impacted permanent maxillary teeth - a case report. Open Dent J 2016; 10:553-60.

11. Uematsu S, Uematsu T, Furusawa K, Deguchi T, Kurihara $S$. Orthodontic treatment of an impacted dilacerated maxillary central incisor combined with surgical exposure and apicoectomy. Angle Orthod 2004; 74: 132.

12. Pinho T, Neves M, Alves C. Impacted maxillary central incisor: Surgical exposure and orthodontic treatment. Am J Orthod Dentofacial Orthop 2011; 140: 256-65.

13. Das D, Misra J. Surgical management of impacted incisors in associate with supernumerary teeth: A combine case report of spontaneous eruption and orthodontic extrusion. J Indian Soc Pedodont Prev Dent 2012; 30:329-32

14. Becker A. Orthodontic Treatment of impacted teeth. 3 rd edition. Wiley-Blackwell, 2012: 56-64

\author{
Sorumlu Yazarın Yazışma Adresi \\ Prof. Dr. Nihat KILIÇ \\ Atatürk Üniversitesi, \\ Diş Hekimliği Fakültesi, Ortodonti Anabilim Dalı \\ Erzurum/Türkiye \\ E-maili: drnkilic@yahoo.com
}

